Federal Reserve Bank of Dallas

Globalization and Monetary Policy Institute

Working Paper No. 171

http:// www.dallasfed.org/ assets/ documents/ institute/ wpapers/2014/ 0171.pdf

\title{
Capital Controls as an Instrument of Monetary Policy ${ }^{*}$
}

\author{
Scott D avis \\ Federal Reserve Bank of D allas \\ Ignacio Presno \\ Federal Reserve Bank of Boston
}

February 2014

Revised: June 2014

\begin{abstract}
Large swings in capital flows into and out of emerging markets can potentially lead to excessive volatility in asset prices and credit supply. In order to lessen the impact of capital flows on financial instability, a number of researchers and policy markers have recently proposed the use of capital controls. This paper considers the benefit of adding capital controls as a potential instrument of monetary policy in a small open economy. In a D SGE framework, we find that when domestic agents are subject to collateral constraints and the value of collateral is subject to fluctuations driven by foreign capital inflows and outflows, the adoption of temporary capital controls can lead to a significant welfare improvement. The benefits of capital controls are present even when monetary policy is determined optimally, implying that there may be a role for capital controls to exist side-by-side with conventional monetary tools as an instrument of monetary policy.
\end{abstract}

JEL codes: F32, F41, E52, E32

* Scott Davis, Federal Reserve Bank of Dallas, 2200 N. Pearl Street, Dallas, TX 75201. 214-922-5124. Scott.davis@dal.frb.org. Ignacio Presno, Federal Reserve Bank of Boston, 600 Atlantic Avenue, Boston, MA 02210. 617-973-3275. Ignacio.presno@bos.frb.org. We would like to thank Mick Devereux, Fabio Ghironi, Kevin Huang, and Albert Queralto for many helpful comments and suggestions. The views in this paper are those of the authors and do not necessarily reflect the views of the Federal Reserve Bank of Dallas, the Federal Reserve Bank of Boston, or the Federal Reserve System. 


\section{Introduction}

Repeated cycles of capital flows into and out of emerging markets is a fixture of the financially integrated global economy. Surges in capital inflows have led to talk of "currency wars" and the danger of overheating in many emerging markets. Likewise, a sudden reversal of capital flows has been blamed for the recent financial and macroeconomic instability in many emerging markets.

Rey (2013) and Forbes and Warnock (2012) show that capital flows into and out of emerging markets are largely driven by global factors. They both show that a measure of global risk is one of the main determinants of international capital flows. Meanwhile, country-specific characteristics are largely irrelevant for driving capital flows into and out of a particular emerging market economy. Reinhart and Reinhart (2008) argue that surges in capital inflows into emerging markets are associated with a higher likelihood of banking, inflation and currency crises, and contribute to economic and financial instability. Kaminsky, Reinhart and Vegh (2004) show that capital inflows are a primary reason for the procyclicality of fiscal and monetary policy observed in many emerging markets. Rey (2013) argues that since these foreign capital flows can lead to asset price bubbles, excess credit creation, and financial instability, capital controls or some tool of active capital account management is necessary in many countries. She argues that this cycle of capital inflows and outflows means that the classic "trilemma" of international finance is actually more of a "dilemma", and that "independent monetary policies are possible if and only if the capital account is managed."1 Klein and Shambaugh (2013) dispute this result and instead argue that a country with an open capital account can still gain considerable monetary autonomy by simply allowing its exchange rate to float.

In a recent paper, the International Monetary Fund (2012) argues that in certain circumstances, active capital controls might be a useful policy instrument to manage the macro-

\footnotetext{
${ }^{1}$ The trilemma of international finance goes back to Mundell (1963) and Fleming (1962) and states that a country cannot at the same time have a fixed exchange rate, an open capital account, and an independent monetary policy.
} 
economic and financial risks associated with large swings in capital inflows and outflows. Cordero and Montecino (2010) argue that capital controls can be a useful tool of monetary policy and can help countries keep inflation under control and also maintain a stable and competitive real exchange rate. Ostry, Ghosh, Chamon and Qureshi (2012) show that while capital controls tend to be of limited use in controlling the aggregate volume of capital flows, inflow controls can be a useful instrument of policy to reduce the financial stability risks associated with surges in capital inflows. In addition, Forbes, Fratzscher and Straub (2013) show that while capital controls tend to be ineffective in managing certain targets like exchange rates, capital flows, interest-rate differentials, inflation, and equity indices, these macroprudential measures can significantly reduce some measures of financial fragility.

Baba and Kokenyne (2011) and Magud, Reinhart and Rogoff (2011) both find that while in practice capital controls do little to affect the volume of capital flows or other key macroeconomic variables, they do tend to "provide room" for monetary policy and tend to make monetary policy more independent in many emerging markets. ${ }^{2}$ Fernández, Rebucci and Uribe (2013) discuss how theory suggests that policy makers should use capital controls countercyclically as a tool of macroprudential policy, but empirically they find that capital controls tend to be acyclical.

The use of capital controls as an instrument of monetary policy when combined with a fixed exchange rate has been part of the international macro literature since Mundell (1963) and Fleming (1962). Jeanne, Subramanian and Williamson (2012) argue that capital controls "properly designed ... might even be a regular instrument of economic policy." (p. 95)

A number of recent papers have addressed this issue of the optimal design of capital controls. Schmitt-Grohe and Uribe (2012b) and Schmitt-Grohe and Uribe (2012a) discuss the optimal use of capital controls in an economy that is the member of a currency union and suffers from downward nominal wage rigidity. They show that capital controls can be a viable instrument of policy to overcome the involuntary unemployment caused by wage rigidity.

\footnotetext{
${ }^{2}$ Similarly Klein (2012) argues that temporary "episodic" capital controls have little effect on many macroeconomic variables.
} 
Here they make use of the constraints imposed by the "trilemma"; in a currency union the country lacks a monetary instrument for stabilization, but capital controls can allow the country to still manipulate the price level and thus the real exchange rate while keeping the nominal exchange rate fixed. Farhi and Werning (2012) reach a similar conclusion, that a counter-cyclical capital controls policy can play a role in macroeconomic stabilization in a small open economy with a fixed exchange rate. Costinot, Lorenzoni and Werning (2011) and De Paoli and Lipinska (2013) both discuss the optimal use of capital controls for dynamic terms-of-trade manipulation.

While these papers consider the role of capital controls as an instrument of monetary policy, usually under a fixed exchange rate regime, they do not address the role of capital controls in fostering financial stability. Korinek (2010), Jeanne and Korinek (2010), Bianchi and Mendoza (2013), Bianchi (2011), Benigno, Chen, Otrok, Rebucci and Young (2013), and Korinek (2013) all discuss how the fact that collateral constraints depend on asset prices, which are subject to fluctuations from capital inflows, leads to over-borrowing and financial vulnerability in a small open economy. Specifically the over-borrowing is caused by a pecuniary externality, where agents don't internalize the effect that their collective actions are having on asset prices, and thus collateral constraints. They discuss how counter-cyclical taxes on capital inflows and other macroprudential measures can be used to offset this externality and reduce financial vulnerabilities.

This paper seeks to combine the insights from these two sides of the literature discussing optimal capital controls. This paper will consider the optimal design of capital controls as an instrument of monetary policy in a model with both sticky prices and collateral constraints. The sticky prices provide a role for conventional monetary policy in macroeconomic stabilization, while the collateral constraints provide a means through which cycles of capital flows into and out of the small open economy cause financial instability. Crucially, the amount that individuals can borrow depends on the value of existing collateral at the current market price. A surge in capital inflows following a foreign shock can push up asset prices and loosen 
the collateral constraint in the small open economy, leading to excess credit-creation.

The externality created by the presence of the asset price in the collateral constraint leads to a role for policy to counter these surges in capital inflows and outflows. We show how this externality leads to a boom-bust cycle in the provision of credit. The response of investment following a surge in capital inflows in a model with a binding collateral constraint can differ strongly from the response in the model with no credit frictions. Optimal taxes on capital inflows and outflows significantly reduce the disparity between allocations in the economy with credit frictions and those in the efficient model. This is true both in a model with flexible prices and in a model with sticky prices, where there is also a role for conventional monetary policy. Thus, even when conventional monetary policy in a small open economy is chosen optimally, capital controls can be used as an additional tool for macroeconomic stabilization and deliver significant welfare gains.

However, this result only holds when borrowers in the small open economy face a collateral constraint. When there is no collateral constraint and price frictions are the only source of distortion in the model, the allocation under optimal conventional monetary policy with an open capital account is identical to the allocation when both conventional monetary policy and capital controls are chosen optimally. Without a friction in the supply of credit that leads to a financial stability objective to monetary policy, as long as conventional monetary policy is chosen optimally, optimal capital account policy is to maintain an open capital account.

This paper will proceed as follows. The theoretical model used to derive these optimal policy results is described in section 2. The model is a two-country sticky price DSGE model, where one country is small relative to the rest of the world. In the model, borrowers face collateral constraints where the amount they can borrow depends on the value of existing collateral at the current market price. We show that in this framework the value of collateral, and thus the amount of borrowing in the small open economy, is subject to fluctuations based on surges of capital inflows and outflows from the rest of the world. The calibration of the 
model is discussed in section 3. The results from the model are presented in section 4 . Here we will examine responses in the home country to a surge in capital inflows from the rest of the world. We will examine these both under the cases of flexible prices (and thus no role for conventional monetary policy) and sticky prices. Finally section 5 concludes with some directions for further research.

\section{The model}

In the model there are two countries, home and foreign. As in the New Open Economy Macro literature in Obstfeld and Rogoff (1995), the home country is size $n$ and the foreign country is size $1-n$. As $n \rightarrow 0$, the model becomes one with a small open economy and the rest of the world.

Each country is populated by representative households, entrepreneurs, and firms. Households supply labor to domestic firms and consume. They are net savers. Entrepreneurs borrow from domestic households to finance a capital stock, and they rent this capital to firms. Due to limited enforcement, entrepreneurs are subject to a collateral constraint and

cannot borrow more than a given fraction of the value of their capital stock. Firms hire labor, rent capital, and produce an output. The output from domestic firms is combined with the output from foreign firms to produce a final good that is used for consumption and investment. Firms are engaged in monopolistic competition and set prices according to a Calvo (1983) style price setting framework. Monetary policy is set according to the solution to a Ramsey problem to maximize total welfare in the economy. The conventional monetary policy instrument in this cash-less economy is the risk-free nominal rate of interest. The central bank in the small open economy also has the potential to impose temporary, episodic taxes or subsidies on capital inflows and outflows in order to deter or encourage capital flows. 


\subsection{Households}

Households supply labor to domestic firms, and lend their savings to domestic entrepreneurs. They consume from their labor income and interest on savings. They are risk-averse and derive utility from consumption and disutility from labor effort.

The representative household maximizes its expected lifetime utility given by:

$$
\max E_{0} \sum_{t=0}^{\infty} \beta^{t} A_{t}\left[\ln \left(C_{t}\right)-\psi\left(H_{t}\right)^{\frac{1+\sigma_{H}}{\sigma_{H}}}\right]
$$

subject to their budget constraint:

$$
\begin{aligned}
& P_{t} C_{t}+B_{t+1}+S_{t} B_{t+1}^{f} \\
= & W_{t} H_{t}+\Xi_{t}+\left(1+i_{t}\right) B_{t}+\left(1-\tau_{t}\right)\left(1+i_{t}^{*}\right) S_{t} B_{t}^{f}\left(1-\chi^{b} S_{t} B_{t}^{f}\right)
\end{aligned}
$$

where $C_{t}$ is consumption by the household in period $t, H_{t}$ is the household's labor effort in the period, $\Xi_{t}$ is profit from domestic firms, returned lump-sum to the household, $B_{t}$ is the household's stock of home currency bonds at the beginning of the period, $B_{t}^{f}$ is the stock of bonds denominated in the foreign currency, $S_{t}$ is the nominal exchange rate in units of the home currency per units of the foreign currency, and $W_{t}$ is the wage rate. The term $\left(1-\chi^{b} S_{t} B_{t}^{f}\right)$ represents a tax on holding foreign bonds. This tax is required to ensure stationarity as in Schmitt-Grohe and Uribe (2003). ${ }^{3}$

The intertemporal preference shock, $A_{t}$, follows the stochastic process:

$$
A_{t}=A_{t-1} e^{\lambda_{t}}
$$

\footnotetext{
${ }^{3}$ In the steady state, foreign bond holding is zero, following a positive shock, the home country may run a current account surplus and thus accumulate a stock of foreign bonds, without this quadratic tax rate, there is nothing to say that they would return to the original steady state where the home country holds no foreign bonds, this tax rate means that when the home country holds a large stock of foreign bonds, $S_{t} B_{t}^{f}>0$, the after tax return on those bonds is lower, meaning that the home country will gradually hold fewer foreign bonds until the stock of foreign bonds returns to the stationary steady state.
} 
where $\lambda_{t+1}=\left(1-\rho_{\lambda}\right) \bar{\lambda}+\rho_{\lambda} \lambda_{t}+\varepsilon_{t}^{\lambda}$, and $\bar{\lambda}>0$ is a constant to ensure that in the steady state, households are net savers and entrepreneurs are net borrowers. $\beta_{t}^{*}=\beta\left(1+\lambda_{t}\right)$

The analogous budget constraint for the foreign household is:

$$
\begin{aligned}
& P_{t}^{*} C_{t}^{*}+B_{t+1}^{*}+\frac{B_{t+1}^{f *}}{S_{t}} \\
= & W_{t}^{*} H_{t}^{*}+\left(1+i_{t}^{*}\right) B_{t}^{*}+\left(1-\tau_{t}^{*}\right)\left(1+i_{t}\right) \frac{B_{t}^{f *}}{S_{t}}\left(1-\chi^{b} \frac{B_{t}^{f *}}{S_{t}}\right)
\end{aligned}
$$

The first order condition of the household's problem with respect to domestic bond holdings yields the familiar Fisher equation that links the nominal interest rate, $i_{t+1}$, to the real interest rate, $r_{t+1}$, and the expected inflation rate, $E_{t}\left(\pi_{t+1}\right)$

$$
i_{t+1}=r_{t+1}+E_{t}\left(\pi_{t+1}\right)
$$

The real interest rate is given by:

$$
r_{t+1}=\frac{\Lambda_{t}}{\beta E_{t}\left(\left(1+\lambda_{t+1}\right) \Lambda_{t+1}\right)}
$$

where $\Lambda_{t}$ is the marginal utility of household consumption.

No arbitrage conditions between home and foreign bonds give rise to the uncovered interest parity conditions (in levels):

$$
\begin{aligned}
\frac{S_{t}}{S_{t+1}} & =\frac{\left(1-\tau_{t+1}\right)\left(1+i_{t+1}^{*}\right)}{1+i_{t+1}}\left(1-\chi^{b} S_{t} B_{t}^{f}\right) \\
\frac{S_{t}}{S_{t+1}} & =\frac{\left(1+i_{t+1}^{*}\right)}{\left(1-\tau_{t+1}^{*}\right)\left(1+i_{t+1}\right)\left(1-\chi^{b} \frac{B_{t}^{f *}}{S_{t}}\right)}
\end{aligned}
$$

From these two interest parity conditions, we can see that in this model the tax on the 
foreign bond holdings of domestic residents, $\tau_{t}$, must approximately equal the negative of the tax on domestic bond holdings of foreign residents, $\tau_{t}^{*}$.

\subsection{Entrepreneurs}

In each country there is a representative entrepreneur. Entrepreneurs supply labor to domestic firms. They own capital and rent this capital to firms. They finance this stock of capital partially with their own equity and partially by borrowing from households. They are risk-averse and derive utility from consumption and disutility from labor effort.

The representative entrepreneur maximizes its expected lifetime utility given by:

$$
\max E_{0} \sum_{t=0}^{\infty} \beta^{t}\left[\ln \left(C_{t}^{e}\right)-\psi\left(H_{t}^{e}\right)^{\frac{1+\sigma_{H}}{\sigma_{H}}}\right]
$$

subject to their budget constraint:

$$
P_{t} C_{t}^{e}+P_{t} I_{t}+b_{t+1}=W_{t} H_{t}^{e}+R_{t} K_{t}+\left(1+i_{t}\right) b_{t}
$$

where $H_{t}^{e}$ is the entrepreneur's labor effort, $W_{t}$ is the wage rate, $K_{t}$ is the stock of home country capital held by the representative home country entrepreneur, $R_{t}$ is the rental rate on capital in the home country, and $b_{t}$ is the stock of bonds held by the entrepreneur. ${ }^{4}$

Capital accumulation is subject to a constant depreciation rate $\delta$ and investment adjustment costs captured by the function $F\left(I_{t}, I_{t-1}\right)$. The stock of capital evolves according to the following capital accumulation equations:

\footnotetext{
${ }^{4}$ Bonds inssued in the home currency can be held by three agents, home country household, home country entrepreneurs, and foreign households. The market clearing condition for the market for bonds denominated in the home country currency is:

$n B_{t}+n b_{t}+(1-n) B_{t}^{f *}=0$. The similar market clearing condition for bonds denominated in the foreign currency is: $(1-n) B_{t}^{*}+(1-n) b_{t}^{*}+n B_{t}^{f}=0$.
} 


$$
\begin{aligned}
& K_{t+1}=(1-\delta) K_{t}+F\left(I_{t}, I_{t-1}\right) I_{t} \\
& K_{t+1}^{*}=(1-\delta) K_{t}^{*}+F\left(I_{t}^{*}, I_{t-1}^{*}\right) I_{t}^{*}
\end{aligned}
$$

where $F\left(I_{t}, I_{t-1}\right)=1-\frac{\kappa}{2}\left(\frac{I_{t}}{I_{t-1}}-1\right)^{2}$.

Given these capital accumulation equations, in a competitive market where existing capital can traded among entrepreneurs, the price of existing capital, $P_{t}^{K}$, is given by:

$$
1=\left(1-\kappa\left(\frac{I_{t}}{I_{t-1}}-1\right) \frac{I_{t}}{I_{t-1}}\right) P_{t}^{K}+\kappa\left(\frac{I_{t+1}}{I_{t}}-1\right)\left(\frac{I_{t+1}}{I_{t}}\right)^{2} \frac{P_{t+1}^{K}}{1+i_{t}}
$$

Due to limited enforcement, entrepreneurs face a collateral constraint, they cannot borrow more than $\theta_{t}$ of the expected value of their capital stock:

$$
-\left(1+i_{t}\right) b_{t+1} \leq \theta_{t} E_{t}\left[P_{t+1}^{K} K_{t+1}\right]
$$

where the load-to-value ratio, $\theta_{t}$, can itself be stochastic and thus a source of credit driven business cycle fluctuations.

\subsection{Final Goods Production}

In each county, final output, which is used for consumption and investment, is produced through a CES combination of home and foreign goods:

$C_{t}+C_{t}^{e}+I_{t}=y_{t}=\left[(\omega)^{\frac{1}{\rho}}\left[\left(\int_{0}^{n} y_{t}^{d}(i)^{\frac{\sigma-1}{\sigma}} d i\right)^{\frac{\sigma}{\sigma-1}}\right]^{\frac{\rho-1}{\rho}}+\left(\omega^{f}\right)^{\frac{1}{\rho}}\left[\left(\int_{n}^{1} y_{t}^{m}(i)^{\frac{\sigma-1}{\sigma}} d i\right)^{\frac{\sigma}{\sigma-1}}\right]^{\frac{\rho-1}{\rho}}\right]^{\frac{\rho}{\rho-1}}$

where $y_{t}^{d}(i)$ is the quantity of goods sold to the home market by home country firm $i$ and $y_{t}^{m}(i)$ is the quantity imported into the home market and sold by foreign country firm $i . \rho$ 
is the elasticity of substitution between home and foreign goods, and $\sigma$ is the elasticity of substitution between goods from different firms within the same country.

From the aggregator function in (4), and its foreign counterpart (not listed), the demand for the output from home country firm $i \in[0 n]$ in both the home and foreign markets is given by:

$$
\begin{aligned}
y_{t}^{d}(i) & =\omega(n)^{\frac{1-\rho}{1-\sigma}-1}\left(\frac{P_{t}(i)}{P_{t}^{d}}\right)^{-\sigma}\left(\frac{P_{t}^{d}}{P_{t}}\right)^{-\rho} y_{t} \\
y_{t}^{m *}(i) & =\omega^{f *}(n)^{\frac{1-\rho}{1-\sigma}-1}\left(\frac{S_{t} P_{t}(i)}{P_{t}^{m *}}\right)^{-\sigma}\left(\frac{P_{t}^{m *}}{P_{t}^{*}}\right)^{-\rho} y_{t}^{*}
\end{aligned}
$$

where $P_{t}(i)$ is the price set by firm $i \in[0 n]$. The Law of One Price holds for the good from firm $i$, so if the good has a price $P_{t}(i)$ in the home market, then its price in the foreign market is $S_{t} P_{t}(i)$, where $S_{t}$ is the nominal exchange rate in units of the foreign currency per units of the domestic currency. Thus the various price indices are given by:

$$
\begin{aligned}
P_{t}^{d} & =\left(\frac{1}{n} \int_{0}^{n}\left(P_{t}(i)\right)^{1-\sigma} d i\right)^{\frac{1}{1-\sigma}} \\
P_{t}^{m} & =\left(\frac{1}{1-n} \int_{n}^{1}\left(\frac{P_{t}^{*}(i)}{S_{t}}\right)^{1-\sigma} d i\right)^{\frac{1}{1-\sigma}} \\
P_{t} & =\left[\omega(n)^{\frac{1-\rho}{1-\sigma}}\left(P_{t}^{d}\right)^{1-\rho}+\omega^{f}(1-n)^{\frac{1-\rho}{1-\sigma}}\left(P_{t}^{m}\right)^{1-\rho}\right]^{\frac{1}{1-\rho}}
\end{aligned}
$$

Home country firm $i \in\left[\begin{array}{ll}0 & n\end{array}\right]$ produces traded goods for the home and foreign markets with the following production technology:

$$
y_{t}^{d}(i)+y_{t}^{m *}(i)=h_{t}(i)^{1-\alpha} k_{t}(i)^{\alpha}-\phi
$$

where $h_{t}(i)$ and $k_{t}(i)$ are the labor and capital employed by the firm in period $t$.

From the firm's cost minimization problem, the demand from firm $i$ for labor and capital 
is given by:

$$
\begin{aligned}
& h_{t}(i)=(1-\alpha) \frac{M C_{t}}{W_{t}}\left(y_{t}^{d}(i)+y_{t}^{m *}(i)+\phi\right) \\
& k_{t}(i)=\alpha \frac{M C_{t}}{R_{t}}\left(y_{t}^{d}(i)+y_{t}^{m *}(i)+\phi\right)
\end{aligned}
$$

Due to sticky output prices, the firm may earn a non-zero profit in certain periods. This profit, $\Xi_{t}(i)=P_{t}^{z}(i) z_{t}(i)-W_{t} h_{t}^{z}(i)-R_{t} k_{t}^{z}(i)$ is returned lump-sum to the households.

Market clearing in the labor and capital markets requires that the total demand for labor by firms is equal to the supply of labor from households and entrepreneurs:

$$
\int_{0}^{n} h_{t}(i) d i=H_{t}+H_{t}^{e}
$$

and the quantity of physical capital employed by firms in period $t$ is equal to the economy's stock of physical capital at the beginning of the period:

$$
\int_{0}^{n} k_{t}(i) d i=K_{t}
$$

Price setting by traded goods firms Firms set prices according to a Calvo style price setting framework. In period $t$, the firm will be able to change its price in the domestic market with probability $1-\xi_{p}$. If the firm cannot change prices then they are reset automatically according to $P_{t}(i)=\pi_{t-1} P_{t-1}(i)$, where $\pi_{t-1}=\frac{P_{t-1}}{P_{t-2}}$.

Thus if allowed to change their price in period $t$, the firm will set a price to maximize:

$$
\max _{P_{t}^{y}(i)} E_{t} \sum_{\tau=0}^{\infty} \beta^{\tau}\left(\xi_{p}\right)^{\tau} \Lambda_{t+\tau}\left\{\Pi_{t, t+\tau} P_{t}(i)\left(y_{t}^{d}(i)+y_{t}^{m *}(i)\right)-M C_{t+\tau}\left(y_{t}^{d}(i)+y_{t}^{m *}(i)\right)\right\}
$$

where $\Lambda_{t}$ is the marginal utility of household consumption in period $t$ and $\Pi_{t, t+\tau}=\pi_{t+\tau-1} \Pi_{t, t+\tau-1}$ 
for $\tau>0$. The firm that is able to change its price in period $t$ will set its price to:

$$
P_{t}(i)=\frac{\sigma}{\sigma-1} \frac{E_{t} \sum_{\tau=0}^{\infty} \beta^{\tau}\left(\xi_{p}\right)^{\tau} \Lambda_{t+\tau} M C_{t+\tau}\left(\omega\left(\frac{\Pi_{t, t+\tau}}{P_{t+\tau}^{d}}\right)^{-\sigma}\left(\frac{P_{t+\tau}^{d}}{P_{t+\tau}}\right)^{-\rho} y_{t+\tau}+\omega^{f *}\left(\frac{S_{t+\tau}}{P_{t+\tau}^{m *}}\right)^{-\sigma}\left(\frac{P_{t+\tau}^{m *}}{P_{t+\tau}^{*}}\right)^{-\rho} y_{t+\tau}^{*}\right)}{E_{t} \sum_{\tau=0}^{\infty} \beta^{\tau}\left(\xi_{p}\right)^{\tau} \Lambda_{t+\tau} \Pi_{t, t+\tau}\left(\omega\left(\frac{\Pi_{t, t+\tau}}{P_{t+\tau}^{d}}\right)^{-\sigma}\left(\frac{P_{t+\tau}^{d}}{P_{t+\tau}}\right)^{-\rho} y_{t+\tau}+\omega^{f *}\left(\frac{S_{t+\tau}}{P_{t+\tau}^{m *}}\right)^{-\sigma}\left(\frac{P_{t+\tau}^{m *}}{P_{t+\tau}^{*}}\right)^{-\rho} y_{t+\tau}^{*}\right)}
$$

If prices are flexible, i.e. $\xi_{p}=0$, then this expression collapses to:

$$
P_{t}(i)=\frac{\sigma}{\sigma-1} M C_{t}
$$

which implies that the firm will change a constant mark-up over its marginal cost.

Write the price set by the firm that can reset prices in period $t$ as $\tilde{P}_{t}(i)$ to denote that it is an optimal price. Firms that can reset prices in period $t$ will all reset to the same level, so $\tilde{P}_{t}(i)=\tilde{P}_{t}$. Substitute this optimal price into the price index $P_{t}^{d}=\left(\frac{1}{n} \int_{0}^{n}\left(P_{t}(i)\right)^{1-\sigma} d i\right)^{\frac{1}{1-\sigma}}$. Since a firm has a probability of $1-\xi_{p}$ of being able to change their price, then by the law of large numbers in any period $1-\xi_{p}$ percent of firms will reoptimize prices, and the prices of $\xi_{p}$ percent of firms will be automatically reset using the previous periods inflation rate. Thus the price index for domestic traded goods, $P_{t}^{d}$, can be written as:

$$
P_{t}^{d}=\left(\xi_{p}\left(\pi_{t-1} P_{t-1}^{d}\right)^{1-\sigma}+\left(1-\xi_{p}\right)\left(\tilde{P}_{t}\right)^{1-\sigma}\right)^{\frac{1}{1-\sigma}}
$$

\subsection{Monetary Policy}

There is a role for monetary policy in the version of the model with sticky prices. Monetary policy in the home economy is characterized as the solution to a Ramsey problem where the policy maker maximizes the second-order approximation of the sum of the home country household and entrepreneur welfare functions in (1) and (2) subject to the first-order conditions and resource constraints for the household, entrepreneur and firm.

Similarly, monetary policy in the foreign economy is the solution to a Ramsey problem 
where the policy maker maximizes the second-order approximation of the sum of the foreign country household and entrepreneur welfare functions.

\section{Calibration and Solution}

The model's parameters and their values are reported in table 1. The first eight parameters in the table, the discount factor, capital's share of value added, the capital depreciation rate, the small constant tax on foreign bond holdings that is used to ensure stationarity, the investment adjustment cost parameter, the probability that a firm cannot change prices in a given period, and the elasticities of substitution between goods from different firms, and between home and foreign traded goods, are all set to values commonly used in the literature. The relative country size parameter, $n$, is set very small to ensure that the home economy is a small open economy and does not have a significant effect on events in the rest of the world. The weights on domestic and foreign goods in the traded goods aggregator function, $\omega$ and $\omega^{f}$, are set such that there is no steady-state home bias in the preference for traded goods. ${ }^{5}$ Since the home country is a small open economy, the equivalent parameters for the rest of the world are $\omega^{*} \approx 1$ and $\omega^{f *} \approx 0$.

The steady state value of the discount factor shock, $\bar{\lambda}$, implies that the first-order excess return is about $3.6 \%$ per year. ${ }^{6}$

The parameter $\bar{\theta}$ measures the entrepreneur's steady state loan to value ratio. We use a value of 0.75 , which is the value used by Liu, Wang and Zha (2013). Iacoviello (2005) estimates this parameter and shows that it lies between 0.55 (for households) and 0.89 (for

\footnotetext{
${ }^{5}$ From the demand functions for domestic and imported traded goods in (5), the steady state import share is: $m=\frac{\int_{n}^{1} P_{t}^{m}(i) y_{t}^{m}(i)}{\int_{0}^{n} P_{t}^{d}(i) y_{t}^{d}(i)+\int_{n}^{1} P_{t}^{m}(i) y_{t}^{m}(i)}=\frac{\omega^{f}(1-n)^{\frac{1-\rho}{1-\sigma}}}{\omega(n)^{\frac{1-\rho}{1-\sigma}}+\omega^{f}(1-n)^{\frac{1-\rho}{1-\sigma}}}$

${ }^{6}$ The steady state risk-free interest rate, $r_{t}=\frac{1}{\beta(1+\bar{\lambda})}-1$, which reflects the household's discount rate, $\beta(1+\bar{\lambda})$. The steady state return on investment, $R_{t}-\delta=\frac{1}{\beta}-1$, which reflects the entrepreneur's discount rate $\beta$. The per annum steady state first-order excess return is then given by $\left(1+R_{t}-\delta-r_{t}\right)^{4}-1 \approx 4 \beta \bar{\lambda}$
} 
firms).

\subsection{Shock process and solution procedure}

The model is solved with a first-order approximation around the steady state where the collateral constraint (3) is binding, as in Iacoviello (2005), Jermann and Quadrini (2012), and Liu et al. (2013).

We will just consider the effect of shocks originating in the rest of the world on the small open home economy. We will consider the optimal policy response to two foreign shocks that would lead to a surge in capital inflows into the small open economy: a foreign discount factor shock, $\lambda_{t}^{*}$, and a shock to the loan-to-value ratio in the foreign entrepreneur's borrowing constraint, $\theta_{t}^{*}$.

We will consider each shock separately. Assume that the foreign discount factor shock is such that it causes a $1 \%$ fall in the foreign real interest rate that has a half-life of one quarter. Assume that the foreign credit supply shock is such that it leads to a $1 \%$ increase in the multiplier on the foreign borrowing constraint that has a half-life of one quarter.

Since each shock is considered separately and the model is solved with a first-order approximation, for the most part the variance of the shocks are immaterial for both simulations and the calculation of optimal policy. The one caveat is that this model is solved with a first-order approximation in the neighborhood of the steady state where the collateral constraint is binding. If a shock that loosens this constraint is "too big" it could result in an equilibrium where the constraint does not bind, and thus our approximation around the binding constraint is inaccurate. The need for the collateral constraint to always bind provides an upper bound on the size of the shocks. In the impulse response diagrams in the next section we will plot the response of the multiplier on the collateral constraint and show that it remains positive under every shock. 


\section{Optimal Capital Controls Policy}

In discussing optimal capital controls policy, we will present the results in two steps. First, we will consider optimal capital controls policy in a model with flexible prices. We will then consider capital controls policy in a sticky price model, and thus in a model where there is already a role for conventional monetary policy. We will ask if when conventional monetary policy instruments are chosen optimally, is there a role for capital controls as an additional instrument of monetary policy.

\subsection{Flexible Prices}

Figure 1 presents the responses of GDP, investment, net exports, the multiplier on the entrepreneurs collateral constraint, the real exchange rate, and taxes on capital outflows in the small open economy following a foreign discount factor shock, $\lambda_{t}^{*}$. As can be seen in the top row of this figure, this foreign discount factor shock leads to a fall in the foreign real interest rate and a rise in foreign GDP.

Impulse responses from three simulations of the model are presented in the figure. In all three simulations there is no price stickiness and the collateral constraint is the only source of frictions in the model. The dotted line assumes that there are no collateral constraints in the home economy, so from the perspective of the home country policy maker, this simulation represents the efficient allocation. The solid line assumes that there are collateral constraints in both the home and foreign economies, but in this simulation there are no barriers to the free flow of capital between countries. The dashed line assumes that there are collateral

constraints in both the home and foreign economies, but home country policy makers have the option of imposing temporary taxes or subsidies on either the returns home residents receive on foreign bonds (controls on capital outflows) or the return that foreign residents receive on home country bonds (controls on capital inflows). In this model with flexible prices, capital controls are the only option available to the policy maker. 
Except for the responses of interest rates and net exports, these responses are expressed as percent deviations from the steady state. The responses of interest rates and net exports are presented as percentage point deviations from the steady state. As can be seen in the figure, this shock to the foreign discount factor leads to an increase in foreign savings and thus a surge in capital inflows into the home economy, as represented by the $1 \%$ fall in home net exports, a $1 \%$ increase in home investment, and the $0.5 \%$ appreciation in the real exchange rate in the efficient allocation. This surge in capital inflows and increase in investment leads to an increase in the price of existing capital. In the version of the model where entrepreneurs face binding collateral constraints, an increase in the price of existing capital loosens this constraint, allowing them to borrow and invest more. The figure shows that the foreign shock leads to a nearly $6 \%$ fall in the multiplier on the borrowing constraint. This then allows entrepreneurs to borrow and invest more and the same foreign shock that led to a $1 \%$ increase in investment in the efficient allocation now leads to a $2.5 \%$ increase in investment and a nearly $3 \%$ fall in net exports.

Thus a surge in capital inflows, combined with a binding collateral constraint and a procyclical price of capital can lead to a credit and investment boom in the small open economy far in excess of what would occur in the efficient allocation without a collateral constraint. The figure shows that when the home country policy maker is allowed to impose temporary taxes or subsidies on capital inflows and outflows, optimally chosen capital controls can curtail many of the "boom" effects following this foreign shock. The figure shows that the policy maker will impose a temporary subsidy on the returns from holding foreign bonds (and thus subsidize capital outflows). Since in this model taxes on capital inflows must be the mirror image of taxes on capital outflows, the policy maker will impose a temporary $1.5 \%$ tax on foreign holdings of home country bonds. And thus in the face of a surge in capital inflows from abroad, the optimal policy is to impose temporary controls on capital inflows. The figure shows that under optimal capital controls, net exports only fall by $1 \%$ following the foreign shock, and this inflow of foreign capital only leads to $0.5 \%$ appreciation in the 
real exchange rate and a $1 \%$ loosening of the borrowing constraint. As a result, investment increases by only 1 to $1.5 \%$ following the foreign shock. Under optimal capital controls policy, the responses of GDP, investment, and net exports are very similar to their responses in the efficient allocation.

Figure 2 presents the responses of these same variables following a shock to the foreign loan-to-value ratio. This shock leads to a sudden increase in the collateral that foreign entrepreneurs need to put up in order to borrow from foreign households, and thus this foreign credit supply shock leads to a fall in foreign investment demand, GDP, and the real interest rate.

As shown in the figure, this foreign credit supply shock leads to a surge in capital inflows into the small open home economy. Just as before with the shock to the foreign discount factor, this shock leads to a fall in home net exports and an increase in home investment under the frictionless, efficient allocation where home country entrepreneurs do not face a borrowing constraint. However, when home country entrepreneurs face a constraint, these responses are magnified. Just as before, the inflow of foreign capital leads to a surge in the price of entrepreneurs' existing capital, which leads to a loosening of the borrowing constraint and a temporary credit boom in the home economy. The figure shows that under an optimally chosen capital controls policy, policy makers will impose temporary controls on capital inflows and are thus able to nearly match the responses under the efficient allocation.

\subsection{Sticky Prices}

Sticky output prices introduce conventional monetary policy as an additional instrument available to the policy maker as well as add an additional friction to the model. The responses in the small open home economy to a foreign discount factor shock that cause a fall in the foreign real interest rate are presented in figure 3. The figure presents the responses under three versions of the model. The dotted line in the figure again represents the efficient allocation where there are no price frictions or collateral constraints (and thus is identical to 
the dotted line in figure 1). The solid line in the figure represents the version of the model where there are price frictions and collateral constraints, conventional monetary policy is chosen optimally, but capital markets remain open. The dashed line in the figure represents the version of the model where policy makers can choose both optimal conventional monetary policy and the optimal set of controls on capital inflows and outflows.

As can be seen in the figure, the surge in capital inflows causes an appreciation in the home country real exchange rate. Under optimal monetary policy, policy makers sharply cut in nominal interest rate in order to discourage capital inflows, but the exchange rate appreciation still leads to a dramatic fall in home country inflation and GDP. As seen in the model without price frictions, the surge in capital inflows leads to an investment boom in the home country. In the version of the model where entrepreneurs face collateral constraints, the surge in capital inflows leads to an increase in the price of existing capital, which leads to a loosening of the borrowing constraint and a boom in credit and investment in excess of what would occur in the efficient allocation.

However, it is interesting to compare the responses in the model without price frictions in figure 1 to those in the model with price frictions, and thus a role for conventional monetary policy, in figure 3. In the model without price frictions, without the use of capital controls, policy makers could do nothing in the face of a surge in foreign capital inflows. The foreign shock led to a $6 \%$ fall in the multiplier on the home country entrepreneur borrowing constraint and a $2.5 \%$ increase in investment (compared to a $1 \%$ increase under the efficient allocation). When price frictions give a policy makers the conventional monetary policy instrument, policy makers can discourage capital inflows by cutting the nominal interest rate. As seen in figure 3, now the foreign discount factor shock only leads to a $3 \%$ fall in the multiplier on the home entrepreneur's borrowing constraint and a $1.5 \%$ increase in investment. This shows that there is a role for conventional monetary policy is curtailing some of the adverse effects of a surge in foreign capital inflows. However, the figure shows that when capital controls are also available as a policy instrument, just as before the policy maker will impose 
a temporary tax on capital inflows. This will curtail some of the surge in capital inflows, leading to a smaller exchange rate appreciation, a smaller drop in inflation, a smaller fall in the multiplier on the borrowing constraint and a smaller boom in investment. Thus the figure shows that conventional monetary policy can react by cutting the nominal interest rate in order to partially curtail any surge in foreign capital inflows, but even when conventional monetary policy is chosen optimally, there is still a role for capital controls as an additional instrument of monetary policy to help counteract the credit boom caused by a surge in capital inflows from abroad.

However, figure 4 shows that the usefulness of capital controls as an additional instrument of monetary policy is entirely due to the fact that entrepreneurs face a borrowing constraint and thus the surge in capital inflows can lead to a loosening of the borrowing constraint and a boom in credit and investment. Figure 4 presents the responses to the same foreign shock, but sticky output prices are the only source of friction in the model. The figure shows that without frictions caused by borrowing constraints, there is almost no difference between optimal conventional monetary policy (solid line) and the combination of optimal conventional monetary policy and optimal capital controls policy (dashed line). The figure shows that even when the policy maker has the option to use capital controls as a policy instrument, capital markets will remain open.

This same exercise, but in response to a foreign credit supply shock that leads to a surge in foreign capital inflows is presented in figure 5. The earlier results continue to hold; even when conventional monetary policy is chosen optimally, there is still a role for capital controls as an additional instrument of monetary policy to help counteract the credit boom caused by a surge in capital inflows from abroad.

\subsubsection{Fixed Exchange Rate}

While it may not constitute optimal conventional monetary policy, it is still interesting to note the responses in the home country to a foreign shock when the home country maintains 
a fixed nominal exchange rate. The "trilemma of international finance" states that a country cannot at the same time maintain a fixed nominal exchange rate, an independent monetary policy, and an open capital account. Without capital controls, conventional monetary policy must be dedicated to maintaining the fixed exchange rate and policy makers don't have an independent monetary instrument.

This scenario is presented in figure 6 . The figure plots the responses in the home economy to the foreign discount factor shock that leads to a surge in foreign capital inflows. The solid line presents the responses when the home country has a fixed exchange rate and an open capital account (there is no independent monetary instrument), the dashed line presents the responses when the home country has an open capital account and monetary policy is chosen optimally (the currency is freely floating, this corresponds to the results presented with the solid line in figure 3), and the dotted line presents the responses when the home country maintains a fixed nominal exchange rate but capital controls still allow it to set monetary policy optimally.

The figure shows that when the exchange rate is fixed but the capital account is open, the home country must match the sharp fall in the foreign nominal interest rate and this leads to an overly accommodative monetary policy, an $8 \%$ increase in GDP, a dramatic loosening of the borrowing constraint, and a $15 \%$ increase in investment. Thus when the capital account is open, a fixed exchange rate is clearly suboptimal. If instead the policy maker is able to impose capital controls, in response to the foreign shock the policy maker will impose temporary capital controls to block the surge in capital inflows. Thus the country can still use an independent monetary policy and there is no need to match the sharp fall in the foreign nominal interest rate. The home country can maintain a fixed nominal exchange rate without the same increase in GDP, investment, and inflation due to an overly accommodative monetary policy.

This same exercise, but in response to a foreign credit supply shock is presented in figure 7. Again, when the home country tried to maintain a fixed nominal exchange rate and an 
open capital account, the loss of an independent monetary policy leads to an outcome that is clearly suboptimal, but the use of temporary capital controls allows the country to maintain a fixed nominal exchange rate without sacrificing macroeconomic stability.

\section{Conclusion}

Dramatic shifts in capital flows into and out of many emerging market economies over the past few years have led some researcher and policy makers to question whether an open capital market is always welfare maximizing. Specifically, surges in capital inflows and outflows can lead to excessive asset price volatility in many emerging markets. If due to limited enforcement, borrowers in these economies are subject to collateral constraints then these fluctuations in asset prices act like an exogenous "shock" on the borrower's collateral constraint. Thus when asset prices are subject to excessive fluctuations from capital inflows and outflows and borrowers face a collateral constraint that is tied to asset prices, there may be a role for policy to control these excessive capital inflows and outflows and reduce this volatility in the borrower's collateral constraint.

Traditionally, capital controls have been thought of as one leg of the Mundell-Fleming "trilemma of international finance". Capital controls were necessary for macroeconomic stabilization since they provided a degree of monetary independence for a country with a fixed exchange rate, but if the exchange rate was allowed to float, capital controls were unnecessary and stabilization could be achieved through monetary policy. However, recent experience has shown that surges in capital inflows and outflows can lead to financial instability even in countries with a floating exchange rate and an independent monetary policy. In a DSGE framework, this paper shows that the benefits of capital controls are present even when monetary policy is determined optimally. Due to the financial instability caused by fluctuations in capital inflows and outflows, there may be a role for capital controls to exist side-by-side with conventional monetary tools as an instrument of monetary policy. 


\section{References}

Baba, Chikako, and Annamaria Kokenyne, 2011, Effectiveness of capital controls in selected emerging markets in the 2000s, IMF Working Papers WP/11/281.

Benigno, Gianluca, Huigang Chen, Christopher Otrok, Alessandro Rebucci, and Eric R. Young, 2013, Capital controls or real exchange rate policy? a pecuniary externality perspective, mimeo.

Bianchi, Javier, 2011, Overborrowing and systemic externalities in the business cycle, American Economic Review 101(7), 3400-3426.

Bianchi, Javier, and Enrique G. Mendoza, 2013, Overborrowing, financial crises, and macroprudential policies, NBER Working Paper No. 16091.

Calvo, Guillermo A., 1983, Staggered prices in a utility-maximizing framework, Journal of Monetary Economics 12, 383-398.

Cordero, José Antonio, and Juan Antonio Montecino, 2010, Capital controls and monetary policy in developing countries, Center for Economic and Policy Research.

Costinot, Arnaud, Guido Lorenzoni, and Iván Werning, 2011, A theory of capital controls and dynamic terms-of-trade manipulation, NBER Working Paper No. 17680.

De Paoli, Bianca, and Anna Lipinska, 2013, Capital controls: A normative analysis, FRBNY Staff Report No. 600.

Farhi, Emmanuel, and Iván Werning, 2012, Dealing with the trilemma: Optimal capital controls with fixed exchange rates, NBER Working Paper No. 18280.

Fernández, Andrés, Alessandro Rebucci, and Martín Uribe, 2013, Are capital controls prudential? an empirical investigation, NBER Working Paper No. 19671.

Fleming, J. Marcus, 1962, Domestic financial policies under fixed and under floating exchange rates, Staff Papers, International Monetary Fund 9, 369-379.

Forbes, Kristin, and Francis E. Warnock, 2012, Capital flow waves: Surges, stops, flight, and retrenchment, Journal of International Economics 88, 235-251.

Forbes, Kristin, Marcel Fratzscher, and Roland Straub, 2013, Capital controls and macroprudential measures: What are they good for?, DIW Berlin Discussion Paper No. 1343.

Iacoviello, Matteo, 2005, House prices, borrowing constraints, and monetary policy in the business cycle, American Economic Review 95(3), 739-764.

International Monetary Fund 2012, The liberalization and management of capital flows: An institutional view. 
Jeanne, Oliver, and Anton Korinek, 2010, Excessive volatility in capital flows: A pigouvian taxation approach, American Economic Review (Papers and Proceedings) 100(2), 403407.

Jeanne, Olivier, Arvind Subramanian, and John Williamson, 2012, Who Needs to Open the Capital Account (Peterson Institute for International Economics, Washington D.C.).

Jermann, Urban, and Vincenzo Quadrini, 2012, Macroeconomic effects of financial shocks, American Economic Review 102(1), 238-271.

Kaminsky, Graciela L., Carmen M. Reinhart, and Carlos A. Vegh, 2004, When it rains it pours: Procyclical capital flows and macro-prudential policies, NBER Working Paper no. 10780.

Klein, Michael W., 2012, Capital controls: Gates vs. walls, NBER Working Paper no. 18526.

Klein, Michael W., and Jay C. Shambaugh, 2013, Rounding the corners of the policy trilemma: Sources of monetary policy autonomy, NBER Working Paper no. 19461.

Korinek, Anton, 2010, Regulating capital flows to emerging markets: An externality view, mimeo. 2013, Capital account intervention and currency wars, mimeo.

Liu, Zheng, Pengfei Wang, and Tao Zha, 2013, Land price dynamics and macroeconomic fluctuations, Econometrica 81(3), 1147-1184.

Magud, Nicloas E., Carmen M. Reinhart, and Kenneth S. Rogoff, 2011, Currency mismatch, openness, and exchange rate regime choice, NBER Working Paper No. 16805.

Mundell, Robert A., 1963, Capital mobility and stabilization policy under fixed and flexible exchange rates, Canadian Journal of Economics and Political Science 29(4), 475-485.

Obstfeld, Maurice, and Kenneth Rogoff, 1995, Exchange rate dynamics redux, Journal of Political Economy 103, 624-660.

Ostry, Jonathan D., Atish R. Ghosh, Marcos Chamon, and Mahvash S. Qureshi, 2012, Tools for managing financial-stability risks from capital inflows, Journal of International Economics 88, 407-421.

Reinhart, Carmen M., and Vincent R. Reinhart, 2008, Capital flow bonanzas: An encompassing view of the past and present, NBER Working Paper No. 14321.

Rey, Helene, 2013, Dilemma not trilemma: The global financial cycle and monetary policy independence, Paper prepared for the Jackson Hole Symposium August 23-25, 2013.

Schmitt-Grohe, Stephanie, and Martin Uribe, 2003, Closing small open economy models, Journal of International Economics 61, 163-185. 
_ 2012a, Managing currency pegs, American Economic Review (Papers and Proceedings) 102, 192-197.

2012b, Prudential policy for peggers, NBER Working Paper No. 18031. 
Table 1: Parameter Values

\begin{tabular}{ccl}
\hline \hline Symbol & Value & Description \\
\hline$\beta$ & 0.98 & discount factor \\
$\alpha$ & .36 & capital share in production of value added \\
$\delta$ & 0.025 & capital depreciation rate \\
$\chi^{b}$ & 0.001 & small constant tax on foreign bond holdings (needed to ensure stationarity) \\
$\kappa$ & 2.48 & investment adjustment cost parameter \\
$\xi_{p}$ & 0.75 & probability that a firm cannot reset prices \\
$\omega$ & 0.73 & weight on domestic goods in the CES aggregator function \\
$\omega^{f}$ & 0.50 & weight on foreign goods in the CES aggregator function \\
$\sigma$ & 10 & elasticity of substitution across varieties from different firms \\
$\rho$ & 1.5 & elasticity of substitution between home and foreign goods \\
$\phi$ & 0.3303 & fixed cost to ensure firms earn zero profit in steady state \\
$n$ & 0.001 & relative size of the home country \\
$\bar{\lambda}$ & 0.0089 & steady state value of discount factor shock \\
$\bar{\theta}$ & 0.75 & steady state value of borrowing limit \\
\hline \hline
\end{tabular}



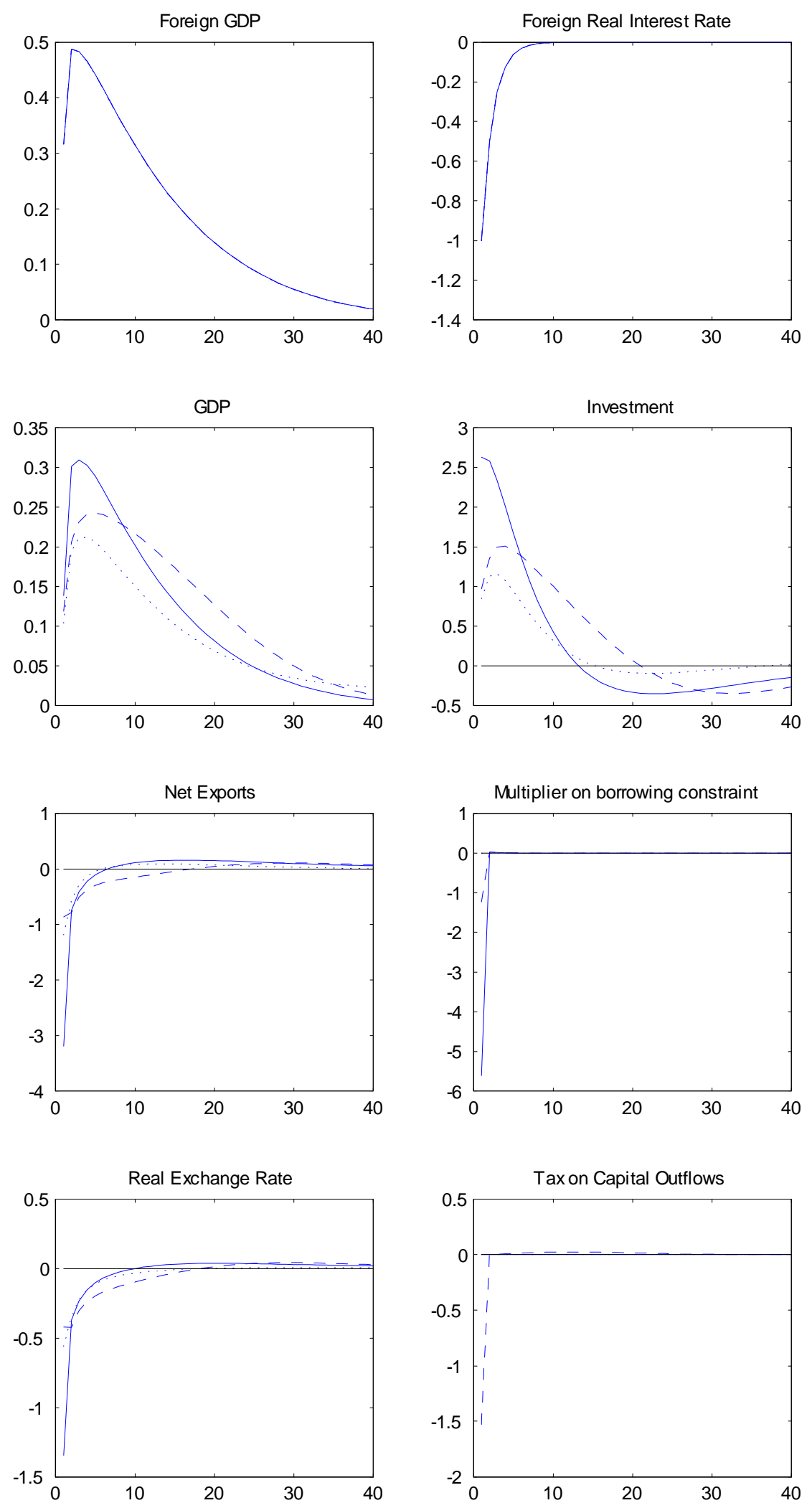

Figure 1: Impulse responses (expressed as percent deviations from the steady state) in the small open economy following a foreign discount factor shock in the model with flexible prices. The dotted line represents the efficient allocation where there are no collateral constraints. The solid line represents the model with collateral constraints and open capital markets. The dashed line represents the model with collateral constraints and where capital controls are chosen optimally. 

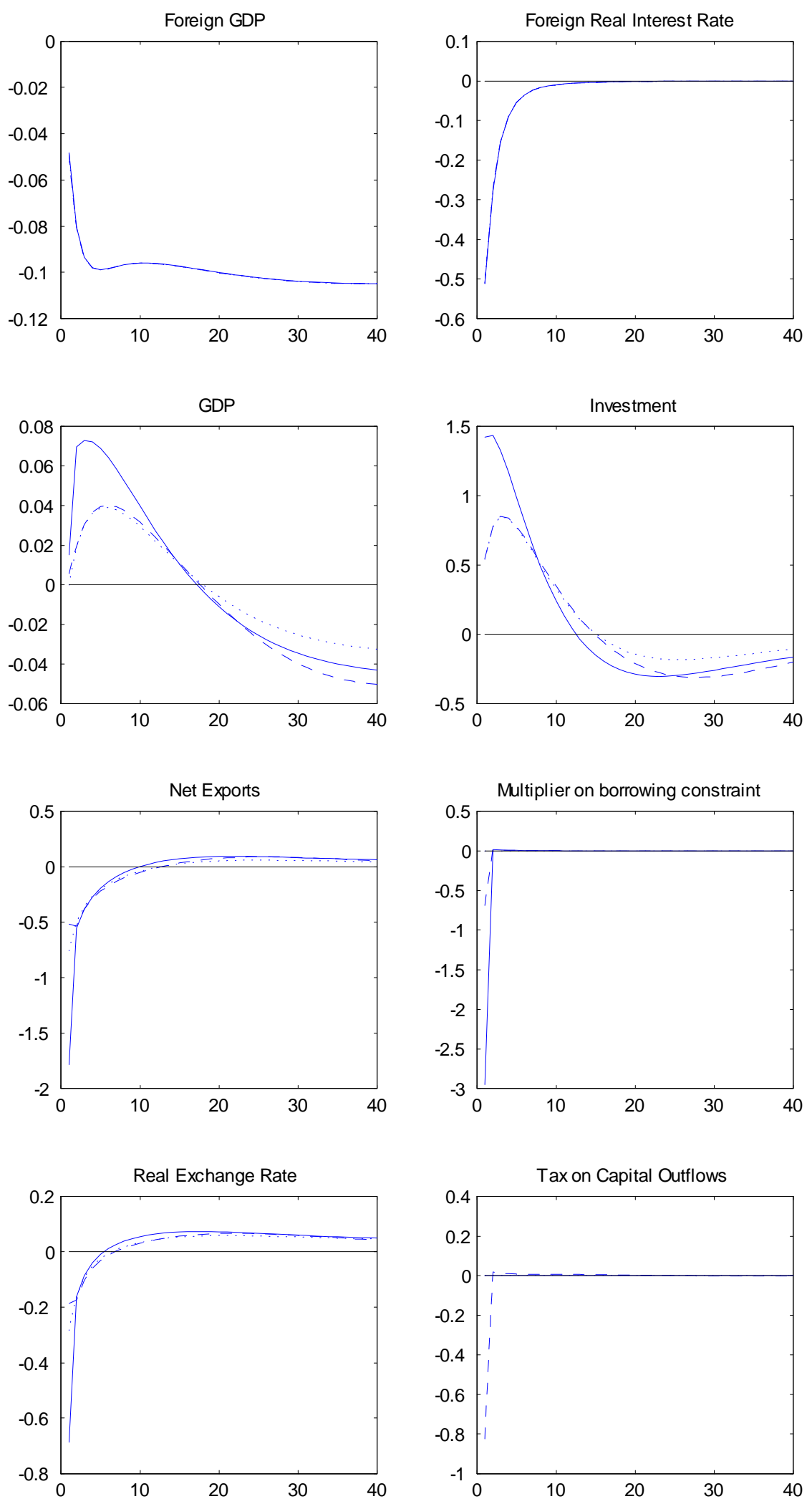

Figure 2: Impulse responses (expressed as percent deviations from the steady state) in the small open economy following a foreign credit supply shock in the model with flexible prices. The dotted line represents the efficient allocation where there are no collateral constraints. The solid line represents the model with collateral constraints and open capital markets. The dashed line represents the model with collateral constraints and where capital controls are chosen optimally. 

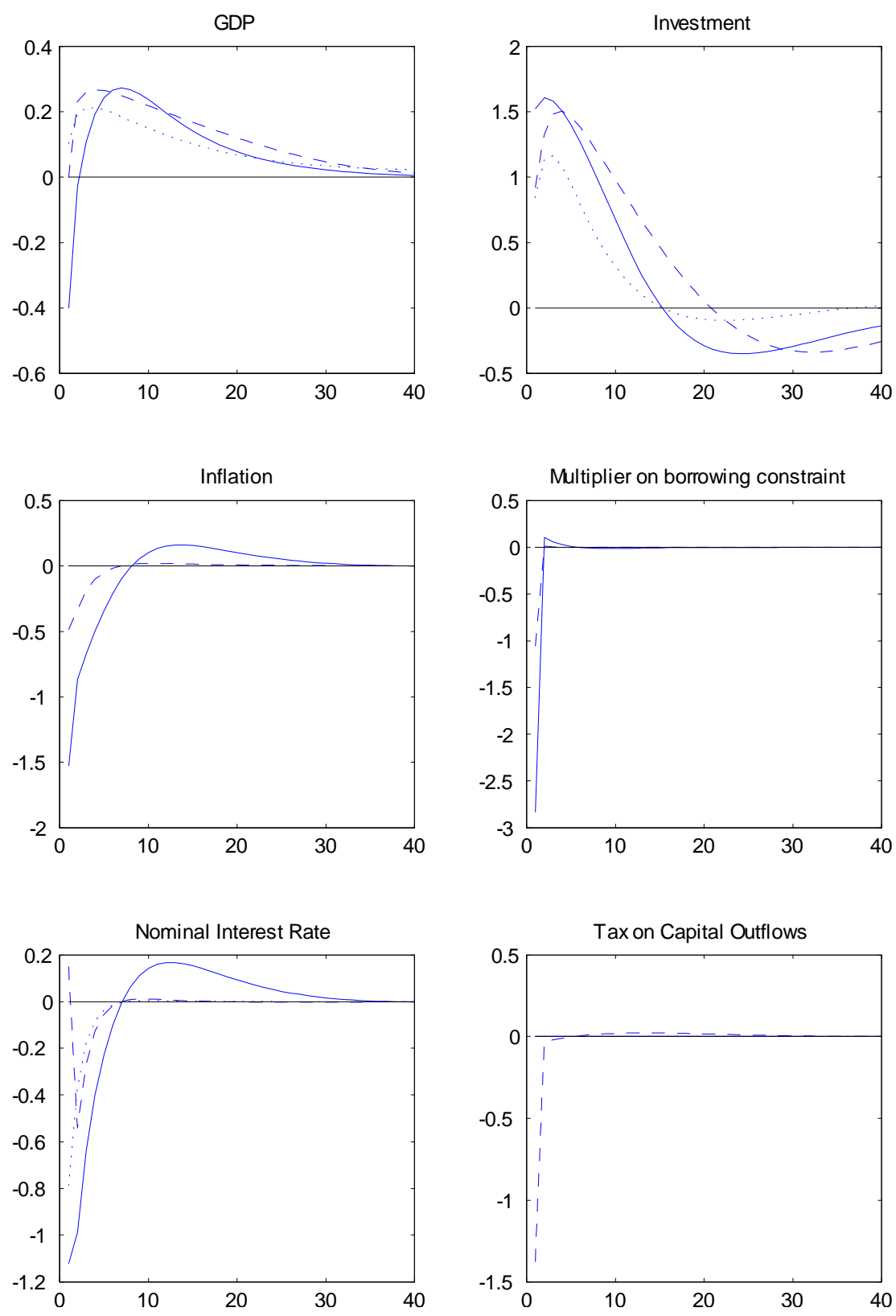

Figure 3: Impulse responses (expressed as percent deviations from the steady state) in the small open economy following a foreign discount factor shock. The dotted line represents the efficient allocation where there are flexible prices and no collateral constraints. The solid line represents the model with sticky prices, collateral constraints and open capital markets. The dashed line represents the model with sticky prices, collateral constraints and where capital controls are chosen optimally. 

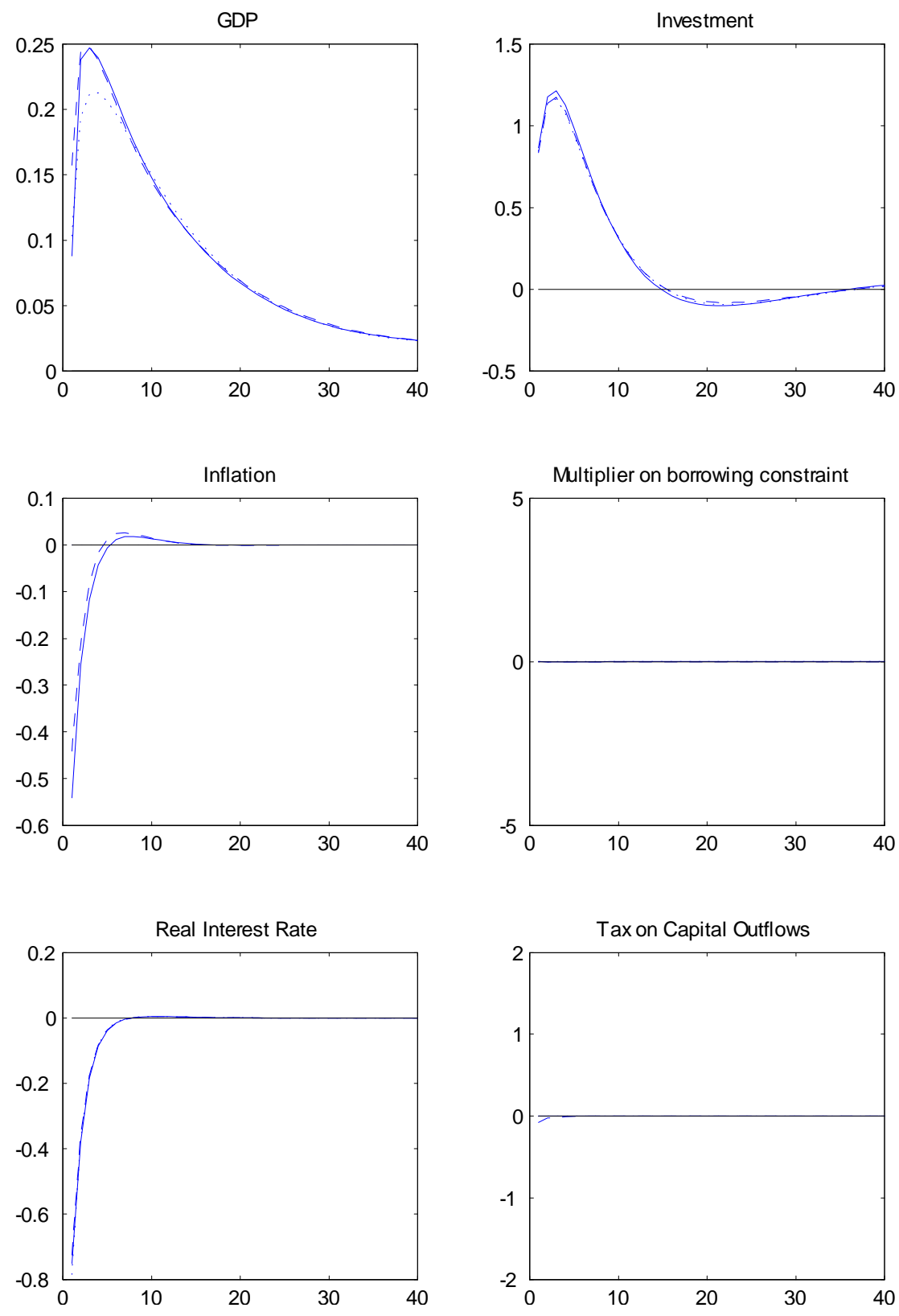

Figure 4: Impulse responses (expressed as percent deviations from the steady state) in the small open economy following a foreign discount factor shock in the model with no credit frictions. The dotted line represents the efficient allocation where there are flexible prices. The solid line represents the model with sticky prices and open capital markets. The dashed line represents the model with sticky prices and optimally chosen capital controls. 

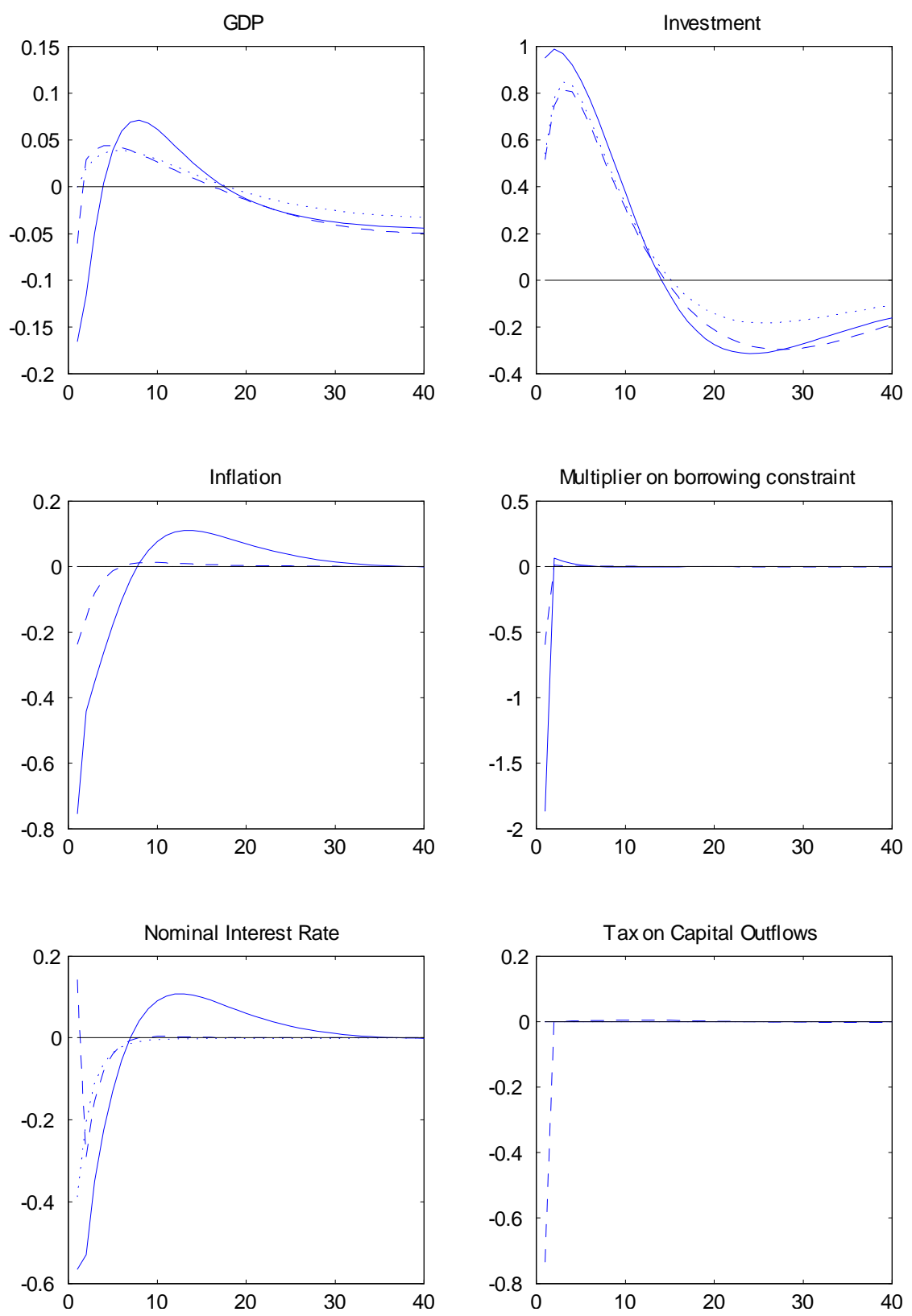

Figure 5: Impulse responses (expressed as percent deviations from the steady state) in the small open economy following a foreign credit supply shock. The dotted line represents the efficient allocation where there are flexible prices and no collateral constraints. The solid line represents the model with sticky prices, collateral constraints and open capital markets. The dashed line represents the model with sticky prices, collateral constraints and where capital controls are chosen optimally. 

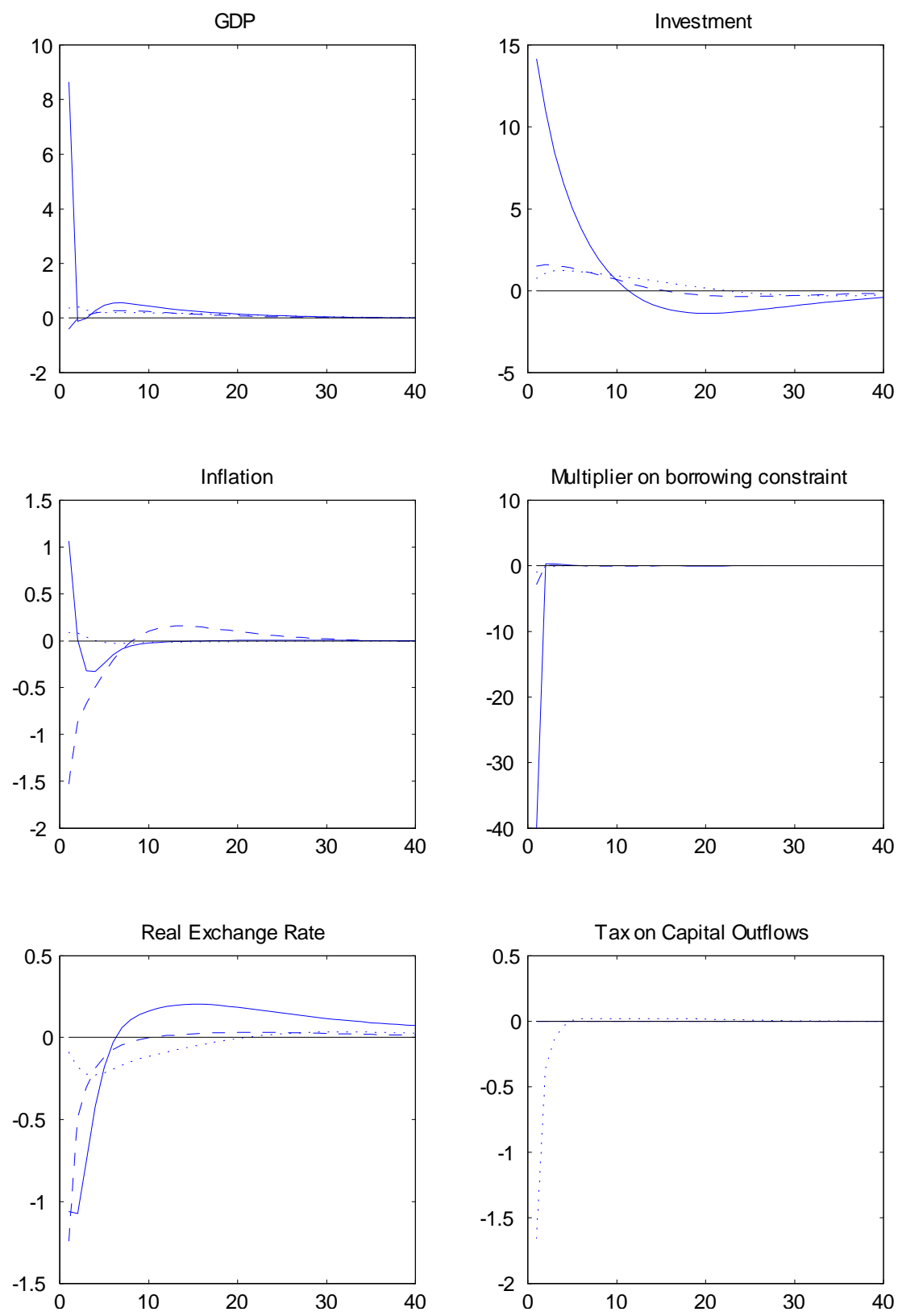

Figure 6: Impulse responses (expressed as percent deviations from the steady state) in the small open economy following a foreign discount factor shock. The solid line represents the model with a fixed nominal exchange rate and an open capital account. The dashed line represents the model with an optimally chosen monetary policy and an open capital account. The dotted line represents the model with a fixed exchange rate and optimally chosen capital controls. 

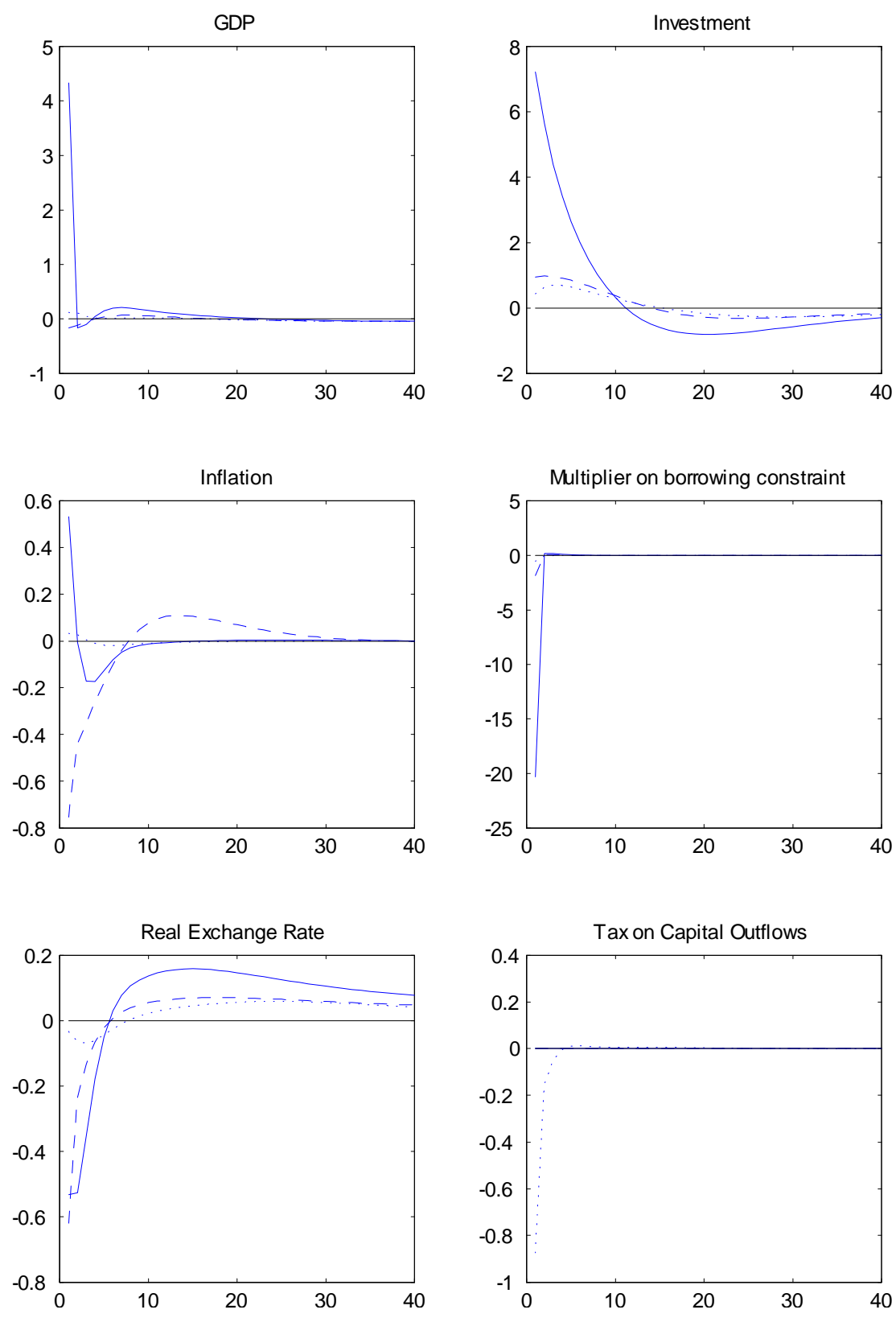

Figure 7: Impulse responses (expressed as percent deviations from the steady state) in the small open economy following a foreign credit supply shock. The solid line represents the model with a fixed nominal exchange rate and an open capital account. The dashed line represents the model with an optimally chosen monetary policy and an open capital account. The dotted line represents the model with a fixed exchange rate and optimally chosen capital controls. 